\title{
Modeling effects of climate change on Yakima River salmonid habitats
}

\author{
James R. Hatten • Thomas R. Batt • Patrick J. Connolly • \\ Alec G. Maule
}

Received: 2 July 2012 / Accepted: 11 October 2013 / Published online: 7 November 2013

C The Author(s) 2013. This article is published with open access at Springerlink.com

\begin{abstract}
We evaluated the potential effects of two climate change scenarios on salmonid habitats in the Yakima River by linking the outputs from a watershed model, a river operations model, a two-dimensional (2D) hydrodynamic model, and a geographic information system (GIS). The watershed model produced a discharge time series (hydrograph) in two study reaches under three climate scenarios: a baseline (1981-2005), a $1-^{\circ} \mathrm{C}$ increase in mean air temperature (plus one scenario), and a $2-^{\circ} \mathrm{C}$ increase (plus two scenario). A river operations model modified the discharge time series with Yakima River operational rules, a 2D model provided spatially explicit depth and velocity grids for two floodplain reaches, while an expert panel provided habitat criteria for four life stages of coho and fall Chinook salmon. We generated discharge-habitat functions for each salmonid life stage (e.g., spawning, rearing) in main stem and side channels, and habitat time series for baseline, plus one (P1) and plus two (P2) scenarios. The spatial and temporal patterns in salmonid habitats differed by reach, life stage, and climate scenario. Seventy-five percent of the 28 dischargehabitat responses exhibited a decrease in habitat quantity, with the P2 scenario producing the largest changes, followed by P1. Fry and spring/summer rearing habitats were the most sensitive to warming and flow modification for both species. Side channels generally produced more habitat than main stem and were more responsive to flow changes, demonstrating the importance of lateral connectivity in the floodplain. A discharge-habitat sensitivity analysis revealed that proactive management of regulated surface waters (i.e., increasing or decreasing flows) might lessen the impacts of climate change on salmonid habitats.
\end{abstract}

This article is part of a Special Topic on "Stakeholder Input to Climate Change Research in the Yakima River Basin, WA" edited by Alec Maule and Stephen Waste.

Electronic supplementary material The online version of this article (doi:10.1007/s10584-013-0980-4) contains supplementary material, which is available to authorized users.

J. R. Hatten $(\bowtie) \cdot$ T. R. Batt • P. J. Connolly • A. G. Maule

U.S. Geological Survey, Western Fisheries Research Center, Columbia River Research Laboratory, Cook, WA 98605, USA

e-mail: jhatten@usgs.gov 


\section{Introduction}

The Yakima River is a 5th-order stream in south-central Washington draining approximately $15,851 \mathrm{~km}^{2}$. Originating in the Cascade Mountains, the Yakima River flows southeasterly for $346 \mathrm{~km}$ to its confluence with the Columbia River near Richland (Fig. 1). Precipitation in the Yakima River Basin varies from $356 \mathrm{~cm}$ annually in the Cascades to less than $25 \mathrm{~cm}$ in the Kennewick area, making water a scarce commodity during summer months at low elevations. In 1905, the Yakima Project was authorized, with six federal reservoirs constructed between 1910 and 1933. The Yakima River is an important spawning and rearing area for numerous salmonid species and stocks, including fall coho Oncorhynchus kisutch, spring and fall Chinook salmon O. tshawytscha, summer steelhead O. mykiss, and bull trout Salvelinus confluentus. Once numbering in the hundreds of thousands, the number of adult anadromous salmonids returning to spawn in the Yakima River Basin has been reduced by over an order of magnitude due to anthropogenic causes (USBR 2002). While irrigation and flood control historically took precedent, reservoir operations, instream flows, and anadromous fish requirements are now also considered at certain times of the water year (USBR 2002).

Climate change, water availability, and fish conservation concerns prompted two important studies in the Yakima River Basin. The first study examined how different water-storage/flow scenarios might affect salmonid habitats in five floodplain reaches of the Yakima River (Bovee et al. 2008) The authors used a two-dimensional (2D) hydrodynamic model (River2D; Steffler and Blackburn 2002) to calculate the velocities, depths, and Froude values for a range of flows ( $5 \%-95 \%$ exceedance), in a 3X3-m grid spacing. An expert panel of regional fish biologists provided information on salmonid species, life stages, and habitat preferences reach by reach, using a Delphi consensus approach (Zuboy 1981). Fish-habitat models were created by linking the 2D flow simulations with habitat criteria provided by the expert panel in each cell, by flow. The authors demonstrated how flow management (i.e., regulated flows) affects the availability and distribution of fish habitat. A second study employed a calibrated watershed model (Mastin and Vaccaro 2002) to simulate how unregulated surface runoff that occurred under baseline temperatures (1981-2005) might change if the mean annual air temperature increased by $1{ }^{\circ} \mathrm{C}$ (P1 scenario) or $2{ }^{\circ} \mathrm{C}(\mathrm{P} 2$ scenario) relative to baseline (Mastin 2008). The author found that each climate scenario produced a unique hydrograph (discharge time series), with the $\mathrm{P} 1$ and $\mathrm{P} 2$ scenarios producing increased flows in late fall and winter, and reduced flows in late spring and summer.

Our study built upon previous studies by examining how climate change may affect coho and fall Chinook salmon habitat in the Gap and Wapato reaches. The USBR modified the three unregulated hydrographs (baseline, P1, P2) output from the watershed model with RiverWare $^{\mathrm{TM}}$ (Zagona et al. 2001), applying Yakima River operating rules specified in the Interim Comprehensive Basin Operating Plan (USBR 2002; Chris Lynch, personal communication). Relying on a fish expert panel (Bovee et al. 2008), we modeled four life stages of coho salmon (spawning, fry, summer rearing, winter rearing) and three life stages of fall Chinook salmon (spawning, fry, spring rearing). Fall Chinook salmon juveniles emigrate from the Yakima River in late spring at age-0, while coho salmon stay to overwinter and emigrate the following spring at age-1. We examined main stem and side channels separately since they often provide different amounts of rearing and spawning habitats for each species (Brown and Hartman 1988; Swales and Levings 1989; Sommer et al. 2001; Limm and Marchetti 2009). We assessed model sensitivity by simulating an increase in spring and summer flows in the Wapato reach, while decreasing them in the Gap reach. We conclude by providing useful information aimed toward mitigating, restoring, and enhancing salmonid habitats that may be affected by climate change in the Yakima River Basin. 


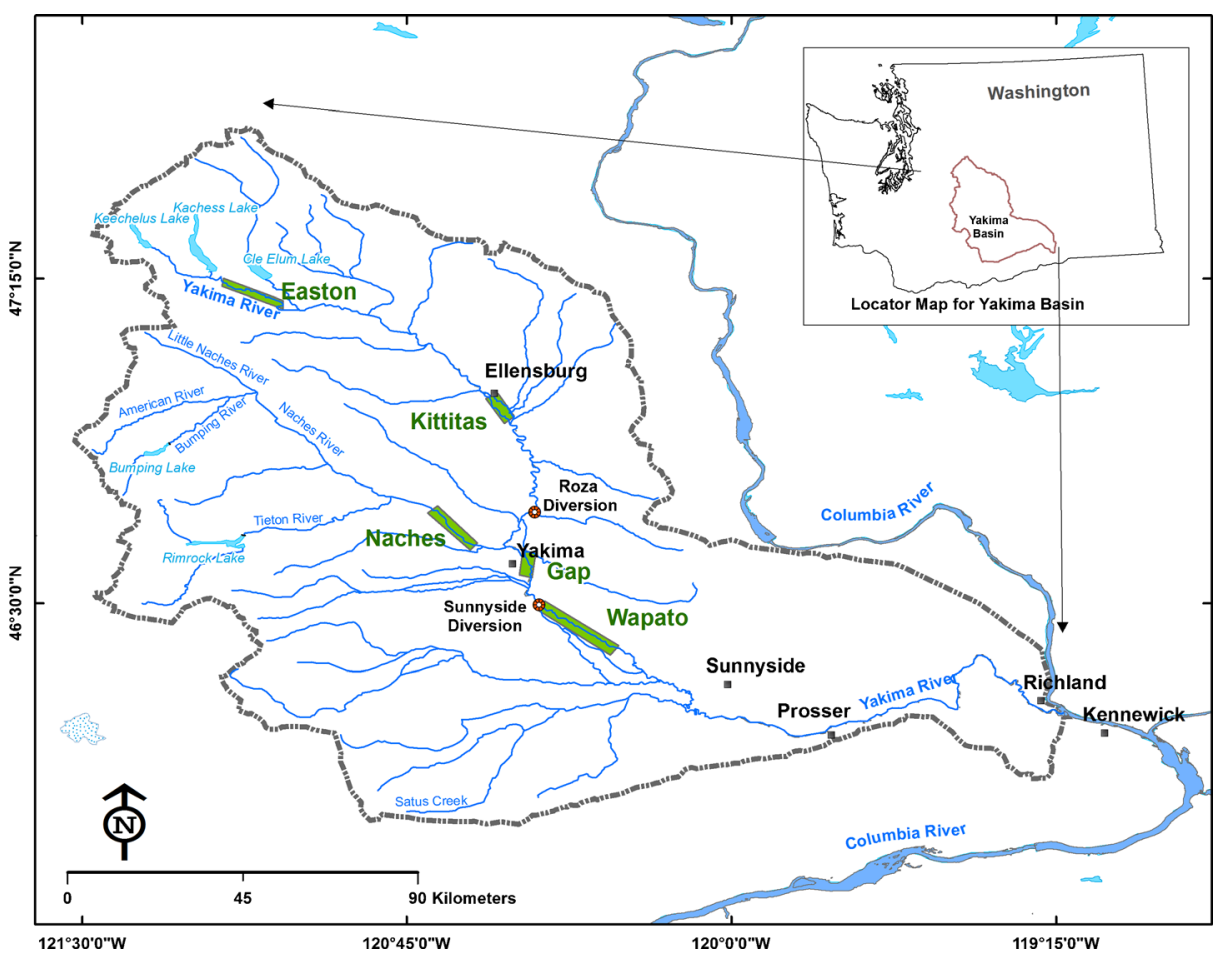

Fig. 1 The location of five reaches that were identified as important to salmonids in the Yakima River in southcentral Washington (Snyder and Stanford 2001; Bovee et al. 2008). The two lower reaches (Gap and Wapato) are the focal areas highlighted in our study

\subsection{Study site}

The Gap and Wapato reaches, located in Yakima County in Central Washington, have broad floodplains and extensive side channels that are important to spawning and rearing salmon (Snyder and Stanford 2001; Stanford et al. 2002). The Gap reach is a large floodplain (1,592 ha) located between the Naches-Yakima confluence and Union Gap, a channel constriction approximately $14 \mathrm{~km}$ downstream (Fig. 1). Despite extensive urban encroachment and revetment, there are numerous secondary channels in this reach that remain interconnected at moderate discharges (Bovee et al. 2008). The Wapato reach has a total valley length of approximately $35 \mathrm{~km}$, extending from Union Gap to the confluence of Satus Creek, near Sunnyside, Washington (Fig. 1). At 3,969 ha (1999 measurement), the Wapato floodplain is the largest of the floodplains in the Yakima Basin (Snyder and Stanford 2001). The modeled section of the Gap reach starts at river $\mathrm{km} \mathrm{178}$, at an elevation of $302 \mathrm{~m}$, and ends at river $\mathrm{km}$ 172, at an elevation of $287 \mathrm{~m}$. The modeled section of the Wapato reach starts at river $\mathrm{km} 166$, at an elevation of $273 \mathrm{~m}$, and ends at river $\mathrm{km} \mathrm{145}$, at an elevation of $240 \mathrm{~m}$.

Due to irrigation uses and operational strategies (USBR 2002), the Sunnyside and Roza diversion dams create different seasonal and annual hydrographs in the Gap and Wapato reaches, even though the two reaches are almost continuous. For example, the Gap reach, headed by the Roza Diversion Dam, has a $5 \%$ exceedance flow of $220.9 \mathrm{cms}$ (i.e., only $5 \%$ of all flows exceed this value), a $50 \%$ exceedance flow of $79.3 \mathrm{cms}$, and a $90 \%$ exceedance flow of $35.4 \mathrm{cms}$ (i.e., $90 \%$ of all flows exceed this value). The Wapato reach, headed by the 
Sunnyside Diversion Dam, has a $5 \%$ exceedance flow of $204.2 \mathrm{cms}$, a $50 \%$ exceedance flow of $35.4 \mathrm{cms}$, and a $90 \%$ exceedance flow of $9.6 \mathrm{cms}$. Both of these reaches have confined channels due to levees and roads in multiple locations, resulting in $90 \%$ exceedance flows being confined largely in the main channels. As flows approach a $5 \%$ exceedance level, the reaches behave differently due to differences in channel morphology. The Gap reach braids into multiple large side channels, but is still confined by roads and levees at the margins. In the Wapato reach, the braided channel is more pronounced with many large and small side channels extending out to cover a much wider floodplain. Both of these reaches are dynamic in that large flow events $(>283 \mathrm{cms})$ cause channel shifting in side and main channels, with more movement evident in the Wapato reach than in the Gap reach.

\section{Methods}

\subsection{Modeling overview}

A habitat time series is the basic building block required to quantify the effects of alternative hydrographs on targeted salmonid habitats (Bovee et al. 1998). Constructing a habitat time series requires a time series of discharges (either baseline or alternative) and a relationship between discharge and habitat area (discharge-habitat function). For every discharge in the flow series, there is a corresponding habitat value from the discharge-habitat function. The watershed model (Mastin 2008) provided the three unregulated hydrographs (baseline, P1, P2), RiverWare ${ }^{\mathrm{TM}}$ modified them with Yakima River operational rules (e.g., storage, diversions, minimum flows), while an expert panel provided fish habitat criteria for each species and life stage (Bovee et al. 2008). Once the datasets were assembled, we evaluated the effects of climate change on salmonid habitats in the Yakima River in four steps. First, we compared and contrasted the three discharge time series modified by RiverWare ${ }^{\mathrm{TM}}$. Second, we generated discharge-habitat functions for each salmonid life stage. Third, we created a habitat time series for each salmonid life stage for each scenario (baseline, P1 or P2). Fourth, we explored the sensitivity of each habitat time series by swapping (substituting) the regulated hydrographs in the Gap and Wapato reaches and recomputing habitat. Our approach was theoretical in order to increase our understanding of a complex aquatic ecosystem and our simulations should be viewed with this goal in mind.

\subsection{Discharge time series}

We determined if our simulated hydrographs under the two climate change scenarios were significantly different from baseline conditions. We compared the shapes of the three regulated hydrographs obtained under baseline, P1 or P2 scenarios, within and between reaches, with a two-sample nonparametric Kolmogorov-Smirnov (KS) test ( $\alpha=0.05$; SPSS). Since the Gap reach is directly above the Wapato reach, differences in $\mathrm{Z}$ scores between simulations (e.g. baseline vs. P2, or P1 vs. P2) are solely attributable to river operational rules and climate change. We examined magnitude and persistence of summer flows since they have a direct bearing on the creation and management of fish habitat in the Yakima River Basin.

\subsection{Discharge-habitat functions}

After averaging mean daily flows between 1981 and 2005 for each climate simulation (baseline, P1, P2), we used a cell-based modeler (GRID; ESRI 1992) and habitat criteria to 
identify fish habitat on a cell-by-cell basis, over a range of steady-state flows in the Gap $(28.317-283.168 \mathrm{cms})$ and Wapato $(8.495-424.753 \mathrm{cms})$ reaches. Habitat criteria provided by an expert panel (Bovee et al. 2008) and the Delphi technique (Zuboy 1981) produced rulebased rather than statistical models of fish habitat. Thus, a location either was or was not habitat depending on water depth, velocity, or channel location. For each flow-based simulation, we combined spatially explicit velocity and depth grids that were produced from a 2D hydraulic model (Bovee et al. 2008) and habitat criteria to determine which cells met the minimum habitat criteria.

We applied the following rules when identifying and quantifying fish habitat. Cells were not considered habitat if they were disconnected from the river at high flow since they would become ever more isolated at lower flows. Conversely, isolated pools in low-water disconnected side channels were considered habitat provided they were connected to the river at a high flow. This approach allows for fish entering stream reaches at higher flows that may subsequently have become isolated at lower flows, while not permitting areas to be considered habitat if fish could not access them at the highest flows.

For our spawning analysis, we only considered cells to be habitat where the Froude number (a dimensionless measure of stream power) was between 0.3 and 0.6 (i.e., riffle habitat) at the highest flow modeled. The rationale for the Froude-number filter is that stream power forms the gravel/cobble complexes (i.e., spawning substrate) at higher flows, while spawning occurs in such complexes at smaller flows (Bovee et al. 2008). An additional criterion for fry habitat was that only locations within three meters of shore were considered habitat (provided they still meet the depth and velocity criteria) since salmonid fry generally seek shallow, slow water (Moore and Gregory 1988; Muhlfeld et al. 2001). Following completion of the habitat simulations for each flow ( $\sim 5 \%-90 \%$ exceedance), we regressed habitat quantity on stream flow and used a curve-fitting routine to select the best statistical relationship (e.g., linear, polynomial, exponential). We summarized habitat by flow in the main stem and side channels separately, and combined. This allowed us to quantify the relative contribution of each channel domain on salmonid habitat, and to develop separate discharge-habitat functions for main stem, side channels, and combined.

\subsection{Habitat trajectories}

Simulating the effects of climate change on salmonid habitat required that we link the discharge-habitat functions developed under steady-state flows to the unsteady-state hydrographs produced from baseline, P1, and P2 simulations. We populated the dischargehabitat functions with average daily flows for a given hydrograph on a daily time step with a statistical program (SPSS, Chicago, Illinois). For example, fall Chinook salmon spring rearing extended from May 1 - June 1, or 32 days. For coho salmon winter rearing, the mean daily time series was 213 days (October 1 - April 30). Our technique produced habitat time series that were ideally suited for box-and-whisker plots and line graphs. By displaying the two graphs side-by-side, we could effectively see how the habitat responses differed for each climate scenario from a temporal perspective. The greater the spread in each hydrograph (by lifestage, species, reach), the further apart the $25^{\text {th }}$ and $75^{\text {th }}$ quartiles were; the further apart the medians, the larger the difference in habitat. In contrast, line graphs allowed us to see the temporal and spatial patterns in habitat, such as whether the future responses crossed the $\mathrm{Y}$ axes of the baseline simulations, diverged, converged, paralleled, or differed little.

We examined four distinct life stages for two species in two reaches, under P1 and P2 scenarios, resulting in 28 possible discharge-habitat responses. We standardized the habitat responses by subtracting each future simulation's (P1 or P2) mean daily habitat value from the 
baseline mean daily value and divided the two quantities (change/mean). We created a bar graph to depict habitat response to climate change by life stage and reach.

\subsection{Sensitivity analysis}

We examined the sensitivity of our models by swapping the Gap and Wapato reach hydrographs (i.e., substituting one for the other) and recalculating habitat under baseline and future scenarios, resulting in 42 unique discharge-habitat combinations. Given that the two hydrographs are different largely due to anthropogenic factors (i.e., Sunnyside and Roza diversions) our approach was useful in determining how fish habitat might change under a modified hydrograph. The Gap reach is held artificially high in the spring and summer months (Roza diversion) while the Wapato reach is artificially low (Sunnyside diversion). Thus, the real effect of swapping the hydrographs was to simulate an increase in flows in the Wapato reach during spring and summer months while decreasing them in the Gap reach.

\section{Results}

\subsection{Discharge time series}

There were significant differences $(Z>2 ; \alpha<0.05)$ in the daily discharge time series under baseline, P1 and P2 climate scenarios, with P2 exhibiting the largest differences (Fig. 2). The Wapato reach was more affected by P1 or P2 scenarios than Gap reach, but both reaches had a relatively similar response between the P1 and P2 scenarios. The winter flows (Dec - Feb) for both reaches were predicted to be larger than baseline flows, with the largest differences observed in January and February. In contrast, spring flow simulations (March - May) were mixed, with early spring showing increased future flows under P1 or P2 scenarios, while late spring had decreased flows compared with baseline. Summer flows are expected to be smaller in the Gap reach all summer, with the largest differences occurring earlier, while only early summer flows are expected to be significantly smaller in the Wapato reach before equalizing with the baseline flow. However, the baseline flow in the Wapato reach is expected to occur approximately 3 weeks earlier under the P1 scenario, and 6 weeks earlier under the P2 scenario. Fall (P1 or P2) flows in the Gap reach were slightly lower in early fall before equalizing with the baseline flow, while little difference between flows was observed in the Wapato reach throughout the fall season.

\subsection{Discharge-habitat functions}

Discharge-habitat functions resulting from the coupling of steady-state flows and habitat criteria were varied, depending on salmonid, life stage and reach (Table 1). The dischargehabitat graphs for each species and life stage, by reach, separated by main stem or side channel, are presented in online supplementary file Figures A1-A16.pdf. In addition, spatially explicit simulations (videos) of velocities and depths over a range of flows are available in two online supplementary files (Gap_depth.wmv; Wapato_velocity.wmv). Additional online supplementary files (videos) show predicted habitat at various flows and life stages for coho and Chinook salmon in both reaches (Gap_Coho_Winter_Rearing.wmv; Wapato_Chinook_Spawn.wmv; Wapato_Coho_Summer_Rearing.wmv; Gap_Chinook_Fry_Rearing.wmv). In each video, the low-flow habitat is shown first ( $\sim 90 \%$ exceedance), followed by successively higher flows, until the maximum is reached ( $\sim 5 \%$ exceedance). 

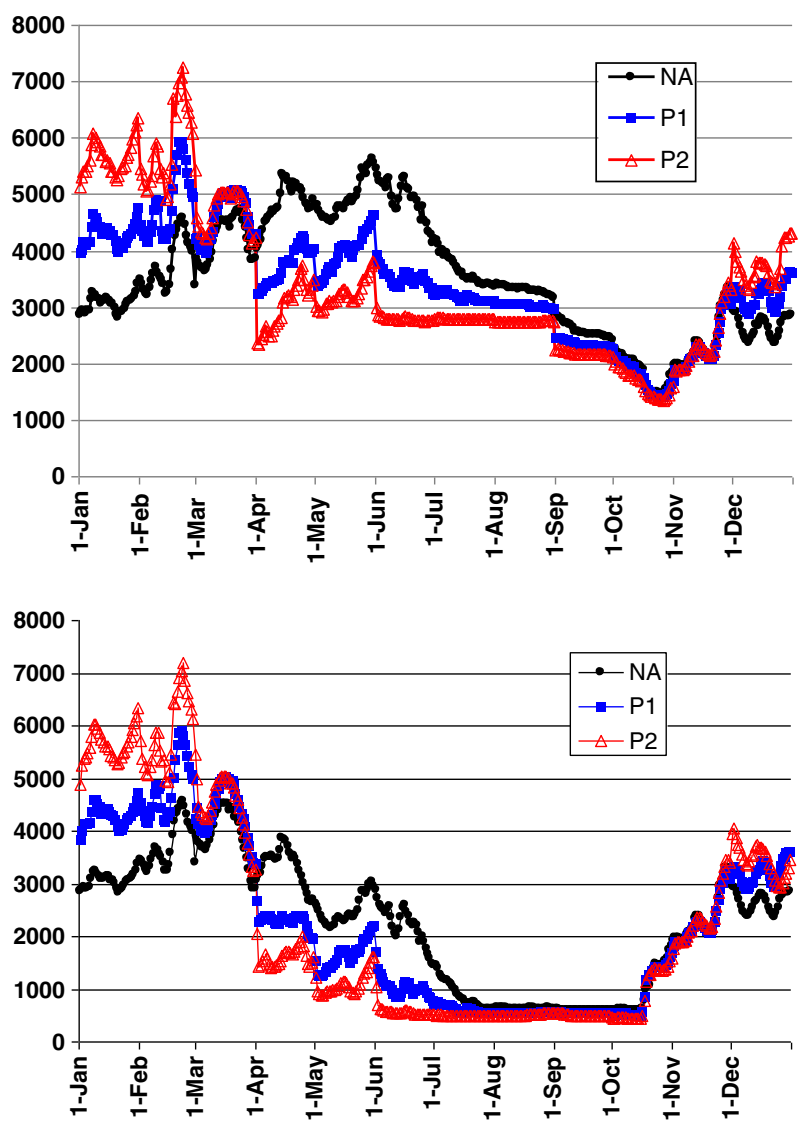

Fig. 2 Three simulated hydrographs in the Gap (top) and Wapato (bottom) reaches, computed with a river operations model (RiverWare ${ }^{\mathrm{TM}}$ ) under standard operational rules in the Yakima River Basin. For each simulation, a watershed model provided Riverware with unmodified mean daily flows (No Action alternative) that were estimated under baseline climatic conditions (NA) between 1981 and 2005 , under a plus $1{ }^{\circ} \mathrm{C}$ mean air temperature increase (P1), and under a plus $2^{\circ} \mathrm{C}$ mean air temperature increase (P2). The $\mathrm{X}$ axis is the date, while the $\mathrm{Y}$ axis is discharge (cfs)

Total fall Chinook salmon spawning habitat increased with flow in a nonlinear fashion in the Gap and Wapato reaches (Table 1, Fig. A1) and the shape of the curves indicated a strong geomorphic constraint to habitat formation. When examined separately, side-channel Chinook spawning habitat increased steadily with flow in both reaches, while main-stem habitat showed small (Gap) to large (Wapato) increases at lower flows, before leveling off and then decreasing at the highest flows.

Total spawning habitat for coho salmon varied dramatically in both reaches by flow (Fig. A2), increasing slightly before declining rapidly in the Gap reach, while increasing steadily in the Wapato reach. This pattern suggests a geomorphic constraint (e.g., channel geometry) limited coho salmon spawning habitat in the Gap reach, but not in the Wapato reach. The pattern of response differed in main stem and side channels, where increasing flows produced more coho spawning habitat in side channels, but less in the main stem.

Total fall Chinook or coho salmon rearing habitat (spring or spring/summer, respectively) increased by flow in a linear fashion for both species and reaches (Figs. A3 and A4), 
Table 1 Discharge-habitat functions for fall Chinook and coho salmon in the Gap and Wapato reaches. Discharge-habitat functions were obtained in two steps. First, fish habitat was identified and quantified over a range of flows (low to high) using GIS and a rule-based model (e.g., correct water depth, velocity, distance to shore). Second, a regression was fit to flows and habitat with a best-fitting curve routine. Figure and panel (top or bottom) are located in the Appendix (Figures A1-A14.doc). In each discharge-habitat function listed below, $\mathrm{x}$ is discharge (cfs) and y is predicted habitat (ha) at a given flow

Life stage Reach Discharge-habitat function

$\mathrm{R}^{2} \quad$ Figure

Fall Chinook spawning

$\begin{array}{llll}\text { Gap } & y=-0.00000009 x^{2}+0.00115045 x+5.02404 & 0.88 & \text { A1 top } \\ \text { Wapato } & y=9.6677 \ln (x)-43.677 & 0.9581 & \text { A2 bottom }\end{array}$

Coho spawning

$\begin{array}{llll}\text { Gap } & y=-0.00000003 x^{2}+0.00018300 x+3.064125 & 0.9121 & \text { A2 top } \\ \text { Wapato } & y=0.0011 x+13.842 & 0.8688 & \text { A2 bottom }\end{array}$

Coho summer rearing

$\begin{array}{llll}\text { Gap } & \mathrm{y}=0.0009 x+6.8144 & 0.9617 & \text { A3 top } \\ \text { Wapato } & \mathrm{y}=0.0035 \mathrm{x}+19.37 & 0.9659 & \text { A3 bottom }\end{array}$

Fall Chinook rearing

$\begin{array}{llll}\text { Gap } & 0.001 \mathrm{x}+8.6972 & 0.9503 & \text { A4 top } \\ \text { Wapato } & \mathrm{y}=0.005 \mathrm{x}+25.487 & 0.9804 & \text { A4 bottom }\end{array}$

Fall Chinook fry

$\begin{array}{llll}\text { Gap } & y=-0.0002 x+7.86 & 0.9772 & \text { A5 top } \\ \text { Wapato } & y=-0.0000001 x^{2}+0.0020227 x+18.2701474 & 0.6536 & \text { A5 bottom }\end{array}$

Coho fry

$\begin{array}{llll}\text { Gap } & y=-0.0002 x+7.8262 & 0.9727 & \text { A6 top } \\ \text { Wapato } & y=-0.0000001 x^{2}+0.0019 x+17.972 & 0.6521 & \text { A6 bottom }\end{array}$

Coho winter rearing

\begin{tabular}{llll} 
Gap & $\mathrm{y}=0.0000001 \mathrm{x}^{2}+0.0001744 \mathrm{x}+16.27845$ & 0.9623 & A7 top \\
Wapato & $\mathrm{y}=-0.0000004 \mathrm{x}^{2}+0.0092228 \mathrm{x}+26.7200276$ & 0.9336 & A7 bottom \\
\hline
\end{tabular}

suggesting no geomorphic constraint in habitat formation. However, an important distinction between these two reaches was the rate of habitat response to flow, with the Wapato reach producing much more coho and Chinook spring/summer rearing habitats by flow than the Gap reach (note the differences in slope). In contrast, side channels produced steadily more coho or fall Chinook spring/summer rearing habitats as flow increased in both reaches, while the main stem produced flat responses.

Fry habitat for both species decreased with increasing flows in a linear fashion in the Gap reach, while habitat increased rapidly before leveling out and then decreasing rapidly in the Wapato reach (Figs A5 and A6, respectively). These patterns indicate a strong geomorphic constraint limited the amount of Chinook and coho salmon fry habitat in the Gap reach, while the amount of habitat in the Wapato reach was very responsive to low to moderate flows before leveling out and then descending. The discharge-habitat functions were markedly different in the main stem and side channels, by reach. Specifically, fry habitat formation for both species was unresponsive to flow in the Gap reach, but decreased steadily with flow in the main stem. In contrast, fry habitat for both species increased rapidly with flow in side channels of the Wapato reach before leveling off, while the main stem showed only a slight positive response in habitat formation at lower flows before becoming sharply negative. 
Coho winter rearing habitat increased with flow in both reaches, with no upper limit identified in the Gap reach, but a ceiling was evident in the Wapato reach (Fig. A7), suggesting a geomorphic constraint. The discharge-habitat functions were markedly different in the main stem and side channels, with coho rearing habitat increasing with flow in side channels of both reaches, but remaining constant in the main stems.

\subsection{Habitat trajectories}

The effects of climate change on Yakima River salmonid habitats were mixed depending on reach, species, and life stage (Table 2). Of the 28 discharge-habitat responses we examined, $75 \%$ showed a decrease in habitat quantity and $25 \%$ showed an increase. In all cases, the P2 scenario produced the largest changes in mean daily habitat compared with baseline. Salmonid life-stage specific habitat responses to individual climate scenarios are shown in box-andwhisker plots and line graphs (A7-A15: online supplementary file Figures A1-A16.pdf).

Chinook salmon fry habitat decreased $7-8 \%$ in the two reaches compared with baseline under the P1 scenario, and between 14 and $16 \%$ under P2 (Table 2). In contrast, coho salmon fry habitat decreased 21-32\% under the P1 scenario, and 36-53\% under P2. The median amount of Chinook salmon fry habitat predicted for each climate scenario differed little within each reach, but the spread in quartiles increased dramatically under P1 and P2 scenarios (Fig. A8). The temporal pattern of fall Chinook fry habitat was a mirror image of itself in the Gap and Wapato reaches, where fry habitat decreased between 1 March and 30 April in both reaches under baseline conditions, increased in the Gap reach under future conditions, but decreased in the Wapato reach. Coho salmon fry habitat increased under P1 and P2 scenarios, but decreased in the Wapato reach between 1 April and 31 May (Fig. A9). The future (i.e., P1, $\mathrm{P} 2$ ) habitat daily time series tracked the baseline estimates, with the $\mathrm{P} 1$ and $\mathrm{P} 2$ producing more coho fry habitat than the baseline in the Gap reach, but less in the Wapato reach.

Fall Chinook salmon spawning habitat decreased $2-4 \%$ in both reaches, with little change observed between climate scenarios (Table 2). The daily habitat time series for fall Chinook salmon spawning habitat was very similar under baseline or future scenarios (Fig. A10). In both reaches, the baseline produced more spawning habitat in the early season, followed by a convergence and then little difference the rest of the season. Spawning habitat for coho salmon increased $10 \%$ in both reaches under the P1 scenario, and increased 17-23\% under P2. The daily spawning habitat time series differed between reaches (Fig. A11). In the first half of the

Table 2 Predicted changes (\%) in fall Chinook and coho salmon habitat (four life stages) in two river reaches, under two climate scenarios (P1 or P2), compared with the daily average habitat modeled under baseline conditions (1981-2005). Fourteen discharge-habitat scenarios were examined under two climate scenarios, resulting in twenty-eight possible outcomes

\begin{tabular}{lllll}
\hline & Coho_P1 & Coho_P2 & Chinook_P1 & Chinook_P2 \\
\hline Gap Spawning & 10.71 & 22.63 & -3.19 & -3.73 \\
Wapato Spawning & 10.58 & 16.85 & -2.40 & -1.88 \\
Gap Rearing & -16.35 & -27.24 & -19.60 & -34.54 \\
Wapato Rearing & -37.16 & -52.18 & -33.83 & -56.02 \\
Gap Fry & -20.89 & -35.89 & -7.17 & -14.40 \\
Wapato Fry & -32.29 & -53.29 & -8.22 & -16.23 \\
Gap Winter & -0.45 & 2.26 & & \\
Wapato Winter & 10.85 & 20.98 & & \\
\hline
\end{tabular}


season (1 November - 1 December) habitat tracked closely in both reaches, then increased steadily under P1 and P2 scenarios in the Wapato reach, while habitat crossovers occurred in the Gap reach.

Fall Chinook salmon spring rearing habitat declined 20-34 \% in the Gap and Wapato reaches under the P1 scenario, and 34-56 \% under P2 (Table 2). The spread in the quartiles decreased in the P1 and P2 scenarios, indicating decreased variability in the daily habitat time series (Fig. A12). Coho salmon spring/summer rearing habitat declined in both reaches $16-37 \%$ under the P1 scenario, and 27-52\% under P2. In both reaches the amount of predicted rearing habitat was substantially more under the baseline conditions in early to mid season, followed by a sharp convergence and little difference in late season (Fig. A13).

Coho salmon winter rearing habitat decreased $4.5 \%$ in the Gap reach under the P1 scenario, while increasing $11 \%$ in the Wapato reach (Table 2; Fig. A14). Winter rearing habitat increased 2-21\% in the Gap and Wapato reaches under the P2 scenario, with the Wapato reach showing the greatest sensitivity (Fig. A15). There were very small differences in the median values for overwintering habitat within each reach, but the spread in the data increased in both future scenarios. The daily time series was unique compared to other life stages because the estimates started out similar, diverged, converged, and then crossed over the baseline in late season. In early season (Oct - Nov) there was close agreement between the habitat estimates, but in mid season (Dec - Feb) the future scenarios increased habitat, followed by a substantial decrease (below the baseline) in late March and April, mirroring the underlying hydrographs.

\subsection{Sensitivity analysis}

A simulated swapping of hydrographs in the Gap and Wapato reaches and a recomputation of habitat resulted in small to large changes depending on reach, species, life stage, or climate scenario (Table 3; Fig. A16). Of the 42 discharge-habitat combinations examined, $67 \%$ showed an increase in habitat and $33 \%$ a negative response. Rearing habitat for both species increased $32-38 \%$ in the Wapato reach, while decreasing 18-23\% in the Gap reach. Fry

Table 3 Changes in simulated salmonid habitats (\%) after we simulated swapping (substituting) the hydrographs in the Gap and Wapato reaches, effectively reducing flows in the Gap reach while increasing them in the Wapato reach. A total of 42 discharge-habitat responses were examined for fall Chinook and coho salmon - four life stages (spawning, rearing, fry, winter), two river reaches (Gap or Wapato), and three climate scenarios (No Action $[\mathrm{NA}]=$ baseline, $\mathrm{P} 1$, or P2)

\begin{tabular}{lllllll}
\hline Reach/life stage & Coho_NA & Coho_P1 & Coho_P2 & Chinook_NA & Chinook_P1 & Chinook_P2 \\
\hline G_W_Spawning $^{\mathrm{a}}$ & -0.01 & -0.01 & 0.13 & -5.67 & -5.46 & -5.31 \\
W_G_Spawning $^{\mathrm{b}}$ & 0.04 & 0.07 & 0.99 & 13.21 & 13.78 & 14.57 \\
G_W_Rearing $^{\mathrm{a}}$ & -22.60 & -22.10 & -20.70 & -17.96 & -18.35 & -17.94 \\
W_G_Rearing $^{\mathrm{b}}$ & 38.17 & 37.66 & 34.88 & 32.26 & 34.46 & 34.55 \\
G_W_Fry $^{\mathrm{a}}$ & 5.77 & 5.37 & 4.92 & 2.50 & 2.41 & 2.29 \\
W_G_Fry $^{\text {W_ }}$ & 9.86 & 11.72 & 12.62 & 4.33 & 4.87 & 5.18 \\
G_W_Winter $^{\mathrm{a}}$ & -5.41 & -3.33 & -2.32 & & & \\
W_G_Winter $^{\mathrm{b}}$ & 15.39 & 11.51 & 9.22 & & & \\
\hline
\end{tabular}

\footnotetext{
${ }^{\text {a }}$ Gap reach hydrograph was replaced with Wapato reach hydrograph

${ }^{\mathrm{b}}$ Wapato reach hydrograph was replaced with Gap reach hydrograph
} 
habitat increased 2-13\% for both species and reaches, with Wapato reach coho habitat appearing most sensitive. Fall Chinook salmon spawning habitat increased in the Wapato reach $13-15 \%$, while increasing $1 \%$ in the Gap reach. Winter rearing habitat for coho salmon resulted in a 9-15\% gain in the Gap reach, and a 2-5\% loss in the Wapato reach.

\section{Discussion}

\subsection{Habitat trajectories}

Of particular concern is the downward projection in fry/rearing habitats for coho and fall Chinook salmon in both reaches. Simulated changes were more extreme for both species under the P2 scenario than P1, and in the Wapato reach where management reduces discharge in spring and summer. A warmer future is expected to produce less water for the Yakima River in the late spring and summer months (Mastin 2008), making the river shallower, less connected to its floodplain, and less suitable for salmonids. One likely response that these rearing-staged fish might have is to move upstream or downstream in search for better habitat. However, upstream movement is impeded by diversion dams, while downstream habitat will be worse due to higher stream temperatures.

Breaking out the main stem from the side channels revealed different patterns in habitat quantity as a response to changes in flow. Of the 14 unique discharge-habitat scenarios we examined in this analysis (Fig. A1-A7), only twice (14\%) did the main stem produce significantly more habitat than side channels (fall Chinook salmon spawning habitat in both reaches). In another three scenarios (21\%), main stems and side channels produced a similar amount of habitat (coho spawning in both reaches, and coho summer rearing (Gap). In the remaining nine reaches $(65 \%)$, side channels produced substantially more habitat than the main stem, indicating the importance of hydrologic connectivity to meet life-stage specific habitat needs (Ebersole et al. 2006).

\subsection{Sensitivity analysis}

Swapping the hydrographs in both reaches increased our understanding of salmonid habitat potential with and without diversion dams. Sixty-seven percent of the 42 discharge-habitat scenarios we examined in this analysis after swapping the hydrographs resulted in increased habitat, while $33 \%$ decreased. Rearing habitat for both species showed large increases in habitat (32-38\%) when we increased flows in the Wapato reach during spring and summer, while moderate losses occurred (18-23\%) in the Gap reach after we decreased discharge. Similar patterns were observed for spawning and winter rearing habitats, where more habitat was achieved for both species after increasing flows in the Wapato reach compared to reduced flows in the Gap reach. The one exception where habitat increased in both reaches for each species was fry habitat, but even in this case the gains in habitat were predicted to be twice as large in the Wapato reach after we simulated increased flows. Thus the habitat gains for each species and life stage achieved through flow augmentation in the Gap reach were negatively offset by the losses in habitat in the Wapato reach due to flow reduction.

\subsection{Decision support}

The minimum base flow set at the Sunnyside Diversion Dam is determined annually by the amount of water in the Yakima River Basin. Outlined in the Interim Operating Plan for the 
Yakima Storage Project (USBR 2002), a balancing act occurs between non-proratable waterright users (those with the most senior rights) and instream flows for fish. High-water years result in larger target (base) flows in the Wapato reach $(\sim 17.0 \mathrm{cms})$ while drier years result in lower base flows $(\sim 8.5 \mathrm{cms})$. The storage control date is the cutoff date when unregulated flows will not be able to supply the minimum flows required under Article XII to support fish habitat unless supplemented with regulated (reservoir release) flows (USBR 2002). Low-water years result in the storage control date being set prior to July 1 while higher-water years result in a later storage control date. The earlier the storage control date is activated, the longer fish will have to survive with minimum base flows. Simulations (Mastin 2008; this publication) indicate this date will come earlier and earlier as the Yakima Basin warms up, resulting in less water being released into the lower Yakima River and a longer and drier summer for salmonids.

A systematic analysis that examines a full range of flows and habitat responses would likely improve our results. Discharge-habitat optimization could form a critical component of a decision support system, enabling managers to visualize changes in a spatially explicit manner with GIS. A decision support system was developed in an earlier study that examined the benefits and tradeoffs between different water-storage scenarios and salmonid habitat in five reaches of the Yakima River (Bovee et al. 2008). A graphically enabled decision support system could simulate hydrographs and habitat time series retrospectively, in real time, or through forecasting. Managers could use decision support to balance the needs of people and fish in the face of a changing climate. Opportunities to do so may arise as agricultural needs shift with climate change or as existing water delivery systems age and need replacement. Our analysis demonstrates that flow augmentation could offset some of the impacts that climate change will have on salmonids in the Yakima Basin.

Acknowledgements We thank Christopher Lynch, U.S. Bureau of Reclamation, Yakima Field Office, Yakima, WA, for providing output from Riverware, Rachel Reagan and Ken Tiffan, U.S. Geological Survey, for text editing and internal review, plus two anonymous reviewers who greatly improved the manuscript. Funding was provided by U.S. Geological Survey, Science Applications and Decision Support Program. Any use of trade, firm, or product names is for descriptive purposes only and does not imply endorsement of the U.S. Government.

Open Access This article is distributed under the terms of the Creative Commons Attribution License which permits any use, distribution, and reproduction in any medium, provided the original author(s) and the source are credited.

\section{References}

Bovee KD, Lamb BL, Bartholow JM, Stalnaker CB, Taylor J, Henriksen J (1998) Stream habitat analysis using the instream flow incremental methodology: U.S. Geological Survey, USGS/BRD/ ITR-1998-0004, $130 \mathrm{p}$.

Bovee KD, Waddle TJ, Talbert C, Hatten JR, Batt TR (2008) Development and application of a decision support system for water management investigations in the Upper Yakima River, Washington. U.S. Geological Survey Open-File Report 2008-1251, 289 p. Available online: http://pubs.usgs.gov/of/2008/1251/ (accessed 6.28.12)

Brown TG, Hartman GF (1988) Contribution of seasonally flooded lands and minor tributaries to the production of coho salmon in Carnation Creek, British Columbia. Trans Am Fish Soc 117:546-551

Ebersole JL, Wigington PJ Jr, Baker JP, Cairns MA, Church MR, Hansen BP, Miller BA, LaVigne HR, Compton JE, Leibowitz SG (2006) Juvenile Coho salmon growth and survival across stream network seasonal habitats. Trans Am Fish Soc 135:1681-1697 
Environmental Systems Research Institute (ESRI) (1992) Cell-based Modeling with GRID, 2nd edn. ESRI, Redlands

Limm MP, Marchetti MP (2009) Juvenile Chinook salmon (Oncorhynchus tshawytscha) growth in off-channel and main-channel habitats on the Sacramento River, CA using otolith increment widths. Environ Biol Fish $85: 141-151$

Mastin MC, Vaccaro JJ (2002) Watershed models for decision support in the Yakima River Basin, Washington: U.S. Geological Survey Open-File Report 02-404, 48 p.

Mastin MC (2008) Effects of Potential Future Warming on Runoff in the Yakima River Basin, Washington. USGS Scientific Investigations Report 2008-5124. Available on-line at: http://pubs.usgs.gov/sir/2008/5124/

Moore KMS, Gregory SV (1988) Summer habitat utilization and ecology of cutthroat trout fry (Salmo clarki) in Cascade Mountain streams. Can J Fish Aquat Sci 45:1921-1930

Muhlfeld CC, Bennett DH, Marotz B (2001) Fall and winter habitat use and movement by columbia river redband trout in a small stream in montana. N Am J Fish Manage 21:170-177

Sommer TR, Nobriga ML, Harrell WC, Batham W, Kimmerer WJ (2001) Floodplain rearing of juvenile chinook salmon: Evidence of enhanced growth and survival. Can J Fish Aquat Sci 58:325-333

Snyder EB, Stanford JA (2001) Review and synthesis of river ecological studies in the Yakima River, Washington, with emphasis on flow and salmon habitat interactions: Final report submitted to U.S. Department of Interior, Bureau of Reclamation, Yakima, Washington. 118 p. plus appendix.

Stanford JA, Snyder EB, Lorang MN, Whited DC, Matson PL, Chaffin JL (2002) The reaches projectEcological and geomorphic studies supporting normative flows in the Yakima River Basin, Washington: Final Report to U.S. Department of Interior, Bureau of Reclamation, Yakima, Washington. $152 \mathrm{p}$.

Steffler P, Blackburn J (2002) Two-dimensional depth averaged model of river hydrodynamics and fish habitatIntroduction to depth averaged modeling and user's manual: Edmonton, University of Alberta, $119 \mathrm{p}$. Available online: http://www.river2d.ualberta.ca/software/River2D.pdf. (accessed 6.28.12)

Swales S, Levings CD (1989) Role of off-channel ponds in the life cycle of coho salmon (Oncorhynchus kisutch) and other juvenile salmonids in the Coldwater River, British Columbia. Can J Fish Aquat Sci 46:232-242

United States Bureau of Reclamation (USBR) (2002) Interim Comprehensive Basin Operating Plan for the Yakima Project, WA. Department of the Interior, United States Bureau of Reclamation, Yakima, WA. 434 p. Available on-line at: http://www.usbr.gov/pn/programs/yrbwep/reports/operatingplan/index.html (accessed 6.28.12).

Zagona EA, Fulp TJ, Shane R, Magee T, Foranflo HM (2001) Riverware: a generalized tool for complex reservoir system modeling. J Am Water Resour Assoc 37:913-929

Zuboy JR (1981) A new tool for fisheries managers: the Delphi technique: N. Am J Fish Manage 1:55-59 